\title{
The "war on drugs" you did not hear about: the global crisis of access to essential anesthesia medications
}

\author{
M. Dylan Bould, CBChB Med • Angela Enright, MD
}

Received: 10 December 2016/Accepted: 15 December 2016/Published online: 4 January 2017

(C) Canadian Anesthesiologists' Society 2017

The review in this issue of the Journal by Nickerson et al. is a thorough, sobering description of how complex international drug regulatory systems-influenced more by politics than by evidence-based assessment of benefits and harm-result in devastating effects on patients in the poorest countries of the world. ${ }^{1}$ These laws, developed with the goal of restricting illicit drug use, instead result in a lack of access to essential medicine that affects only lowand middle-income countries. Other authors have found that these drug laws that were intended to improve public health have resulted in "lethal violence, communicable disease transmission, discrimination, forced displacement, unnecessary physical pain, and the undermining of people's right to health". ${ }^{2-4}$

These laws have huge implications for anesthesia, critical care, and pain management globally. Their establishment has created an excessive bureaucracy that effectively makes it almost impossible in low-resource settings to comply with regulations and ensure access to these medicines. The end results are tragic. Almost $80 \%$ of the world's population lack access to opioids when needed, and palliative care patients die with uncontrolled pain. ${ }^{1}$ The global burden of pain is vast. One in five patients suffer pain, and one in ten have chronic pain. ${ }^{5,6}$ Ongoing threatened "scheduling" of ketamine (i.e., being included on the list of internationally regulated drugs) risks eliminating the only safe option for anesthesia in many

M. D. Bould, CBChB Med ( $\square)$

Children's Hospital of Eastern Ontario, University of Ottawa,

Ottawa, ON, Canada

e-mail: dbould@cheo.on.ca

A. Enright, MD

Royal Jubilee Hospital, University of British Columbia, Victoria, BC, Canada areas of the world. Indeed, in some hospitals, ketamine is currently the only available anesthetic drug. ${ }^{7,8}$

We should ask the question: What is the evidence that international drug regulations are effective at reducing the public health impact of abuse of the medicines that they control? The "War on Drugs", a phrase coined during the 1970s, has dragged on for decades, seemingly endlessly and without progress. Deaths due to opioid overdose in Canada are high and increasing. ${ }^{9}$ Despite the regulations, and in contrast to the situation in poor countries, prescription opioid use is high in Canada. ${ }^{10}$ The spectrum of drug control goes from complete prohibition, through various degrees of regulation, to legalization. There is evidence, however, that less restrictive policies focusing on harm reduction are a more effective public health approach. $^{11}$

International laws and regulations apply equally to all member states. The regulation of controlled drugs, however, is an equity issue. Indeed, this is an example where equal treatment results in dramatically unequal consequences. Prioritizing control of illicit drugs for rich countries results in an over-burdensome regulatory environment for access to much needed medications in poor countries. Nickerson and colleagues point out something that is even more concerning: that the medical and scientific opinions of the World Health Organization seem to be ignored by the United Nations' drug agencies. ${ }^{1}$

Nickerson et al. have highlighted the importance of the global anesthesia community working together to counter the threat of ketamine becoming "the new morphine"-i.e., a drug that is often available only to patients from wealthy countries. The motion to schedule ketamine was not voted on at the $59^{\text {th }}$ session of the Commission on Narcotic Drugs (CND) in March 2016, and the problem has not gone away. China elected to postpone the vote on this motion because of 
the significant opposition to it but still appears to want it scheduled. The motion can be brought back to the CND at any future session. ${ }^{1}$ There has been effective advocacy by the anesthesia community, notably led by the World Federation of Societies of Anaesthesiologists (WFSA), and these efforts must continue. It is an ethical imperative for international and national anesthesia organizations and societies, as well as individual anesthesiologists, to support this stance. It is especially important for anesthesiologists in high-income countries, such as Canada, to speak out on behalf of their anesthesia colleagues in the poorest countries of the world. ${ }^{12}$

Although the imminent threat is to ketamine, it is not the only problem. The damage due to international laws regulating morphine and other opiates has already been done. It is time for the anesthesia community to intensify advocacy efforts to raise awareness of the devastating effects of the lack of access to opiates for the majority of the world's population. The original goals of the international regulatory agencies for controlled drugs were to balance the needs of limiting illicit use while allowing medicinal access. These organizations have failed profoundly to achieve this balance. The anesthesia community must lobby governmental and supra-national organizations to rebalance these international regulations. As healthcare professionals, we are in a unique position to describe the damage that occurs because of the lack of access to essential medicines. ${ }^{13}$ Ketamine and opiates are at the heart of our anesthesia community's responsibilities for health advocacy at a global level. Hence, we must act now to limit the crisis that is restricting access to these essential medications.

\section{La « guerre contre les drogues » dont vous n'avez pas entendu parler : la crise mondiale de l'accès aux médicaments essentiels pour l'anesthésie}

Le compte rendu présenté dans ce numéro du Journal par Nickerson et coll. est une description à la fois détaillée et effarante de la manière dont des systèmes internationaux tortueux de réglementation médicamenteuse, influencés davantage par la politique que par une évaluation factuelle des bienfaits et des torts, ont pour conséquences des effets dévastateurs sur les patients dans les pays les plus pauvres de la planète. ${ }^{1}$ Ces lois, élaborées dans le but de restreindre l'utilisation illicite de drogues, ont eu pour effet de couper l'accès à des médicaments essentiels et n'affectent que les pays à revenu faible à intermédiaire. D'autres auteurs ont déjà observé que ces lois sur les drogues, dont l'objectif initial était d'améliorer la santé publique, ont en fait engendré « une violence mortelle, la dissémination de maladies transmissibles, la discrimination, les déplacements forcés, des douleurs physiques inutiles, en plus de saper le droit humain à la santé $»^{2-4}$

Ces lois ont d'énormes implications pour l'anesthésie, les soins intensifs et la prise en charge de la douleur dans le monde. Elles se nourrissent d'une bureaucratie excessive qui, en réalité, rend quasi impossible le respect des lois et l'accès à ces médicaments dans les contextes où les ressources sont rares. Les conséquences ultimes de cette situation sont tragiques : près de $80 \%$ de la population mondiale n'a pas accès à des opioïdes lorsque elle en a besoin et des patients de soins palliatifs meurent partout dans une douleur non maîtrisée. ${ }^{1}$ Le fardeau mondial de la douleur est immense : un patient sur cinq souffre de douleur et un patient sur dix de douleur chronique. ${ }^{5,6}$ La menace toujours présente d'une « réglementation » de la kétamine, soit son inclusion sur la liste des médicaments réglementés à l'échelle internationale, risque d'éliminer la seule option sécuritaire pour pratiquer l'anesthésie dans de nombreuses régions du monde. En effet, dans certains hôpitaux, la kétamine est actuellement le seul médicament anesthésique disponible. ${ }^{7,8}$

Nous devrions poser la question suivante : quelles sont les données qui soutiennent que les réglementations internationales sur les drogues sont efficaces pour réduire l'impact sur la santé publique des abus des médicaments qu'elles régissent? La "guerre contre les drogues », une expression consacrée dans les années 1970, s'étire depuis des dizaines d'années, sans fin apparente et sans progrès notoire. Au Canada, le nombre de décès provoqués par une surdose d'opioïdes est élevé et augmente. ${ }^{9}$ Malgré ces lois, et contrairement à la situation dans les pays pauvres, l'utilisation d'opioïdes de prescription est également élevée au Canada. ${ }^{10}$ Le contrôle des drogues va de la prohibition complète à la légalisation en passant par différents degrés de réglementation; selon certaines données, il semblerait que des politiques moins restrictives, se concentrant davantage sur la réduction des conséquences négatives, constitueraient une approche de santé publique plus efficace qu'une interdiction pure et simple. ${ }^{11}$

Les lois et réglementations internationales s'appliquent de façon égale à tous les états membres. Toutefois, la réglementation des drogues contrôlées est une question d'équité. En effet, il s'agit là d'un exemple flagrant où un traitement égal pour tous entraîne des conséquences drastiquement inégales. La priorisation du contrôle des drogues illicites dans les pays riches crée un environnement législatif excessif qui restreint l'accès aux médicaments dont on a grandement besoin dans les pays pauvres. Nickerson et ses collègues signalent une situation 
encore plus préoccupante: il semblerait que l'opinion médicale et scientifique de l'Organisation mondiale de la santé soit ignorée par les agences du médicament des Nations unies.

Nickerson et coll. ont souligné l'importance cruciale que la communauté mondiale de l'anesthésie travaille ensemble afin de contrecarrer la menace que la kétamine ne devienne « la nouvelle morphine » - c'est-à-dire, un médicament disponible exclusivement pour les patients des pays riches. La motion qui vise à contrôler la kétamine n'a pas été soumise au vote lors de la $59^{\mathrm{e}}$ séance de la Commission des stupéfiants (CND) en mars 2016, mais le problème n'a pas pour autant disparu. La Chine a décidé de reporter le vote sur cette motion en raison de l'importante opposition qu'elle a rencontrée, mais il semblerait qu'elle veuille toujours que ce médicament soit réglementé; la motion pourrait donc être rapidement remise à l'ordre du jour d'une séance future de la CND. ${ }^{1}$ Un travail de plaidoyer efficace a été accompli par la communauté de l'anesthésie, sous l'égide notable de la Fédération mondiale des sociétés d'anesthésiologistes (WFSA), mais ces efforts doivent se poursuivre. Il s'agit là d'un impératif éthique: les organismes et sociétés d'anesthésie à l'échelle internationale et nationale doivent soutenir ces efforts - et c'est aussi le devoir de chaque anesthésiologiste. Il est particulièrement important que les anesthésiologistes dans les pays à revenu élevé, tels que le Canada, plaident au nom de leurs collègues anesthésistes pratiquant dans les pays les plus pauvres de la planète. ${ }^{12}$

Bien que la menace imminente touche aujourd'hui la kétamine, le problème ne se limite malheureusement pas à cet agent. Les torts causés par les lois internationales régissant la morphine et les autres opiacés sont déjà faits. Il est temps que la communauté de l'anesthésie intensifie ses efforts pour conscientiser le grand public aux effets dévastateurs d'un manque d'accès aux opiacés pour la majorité de la population mondiale. Les objectifs initiaux des agences de réglementation internationales concernant les substances contrôlées étaient de trouver un équilibre entre la nécessité de limiter l'utilisation illicite de drogues et de permettre un accès médicinal à certains agents. L'échec de ces organismes à trouver un tel équilibre est consternant. La communauté de l'anesthésie doit exercer des pressions sur les organismes gouvernementaux et supranationaux afin qu'ils réévaluent ces réglementations internationales et trouvent un équilibre. En tant que professionnels de la santé, nous sommes dans une position privilégiée pour décrire les torts qui surviennent lorsque les médicaments essentiels sont inaccessibles. ${ }^{13} \mathrm{La}$ kétamine et les opiacés sont au cœur des responsabilités de la communauté anesthésique en ce qui touche à la défense de la santé mondiale et nous devons agir aujourd'hui si nous souhaitons mitiger la crise qui restreint l'accès à ces médicaments essentiels.
Conflicts of interest A. Dylan Bould is a member of the education committee of the WFSA and the Chair of CASIEF. Angela Enright is a previous President of the WFSA and a board member and previous Chair of CASIEF.

Editorial responsibility This submission was handled by Dr. Hilary P. Grocott, Editor-in-Chief, Canadian Journal of Anesthesia.

Conflit d'intérêt A. Dylan Bould est un membre du comité de formation de la WFSA, et le président de la FÉI SCA. Angela Enright est une ancienne présidente de la WFSA et est également membre du comité et ancienne présidente de la FÉI SCA.

Responsabilité éditoriale Cet article a été traité par Dr Hilary P. Grocott, rédacteur en chef, Journal canadien d'anesthésie.

\section{References}

1. Nickerson JW, Pettus $K$, Wheeler KE, et al. Access to controlled medicines for anesthesia and surgical care in low-income countries: a narrative review of international drug control systems and policies. Can J Anesth 2017; 64. DOI: 10.1007/ s12630-016-0805-9.

2. Iacobucci G. "War on drugs" has harmed public health and human rights, finds new analysis. BMJ 2016; 352: i1742.

3. Csete J, Kamarulzaman A, Kazatchkine $M$, et al. Public health and international drug policy. Lancet 2016; 387: 1427-80.

4. Khenti A. The Canadian war on drugs: structural violence and unequal treatment of Black Canadians. Int J Drug Policy 2014; 25: 190-5.

5. Enright A, Goucke R. The global burden of pain: the tip of the iceberg? Anesth Analg 2016; 123: 529-30.

6. Jackson T, Thomas S, Stabile V, Shotwell M, Han X, McQueen K. A systematic review and meta-analysis of the global burden of chronic pain without clear etiology in low- and middle-income countries: trends in heterogeneous data and a proposal for new assessment methods. Anesth Analg 2016; 123: 739-48.

7. Cottrell JE, Hartung J. Ketamine versus special K: a doubleedged sword. Anesth Analg 2016; 122: 586.

8. Joshi GP, Onajin-Obembe B. The role of ketamine in low- and middle-income countries: what would happen if ketamine becomes a scheduled drug? Anesth Analg 2016; 122: 908-10.

9. Britten L. CBC News, British Columbia. Overdose deaths up from 40 a month in 2015 to 64 a month this year. Available from URL: http://www.cbc.ca/news/canada/british-columbia/opioidoverdose-deaths-emergency-1.3580212 (accessed December 2016.

10. Weeks $C$, Howlett $K$. The Globe and Mail. Prescriptions of opioid drugs skyrocketing in Canada - April 2016. Available from URL: http://www.theglobeandmail.com/news/national/sales-of-opioddrug-prescriptionsskyrocketing/article26008639/ (accessed December 2016)

11. Ritter A, Cameron J. A review of the efficacy and effectiveness of harm reduction strategies for alcohol, tobacco and illicit drugs. Drug Alcohol Rev 2006; 25: 611-24.

12. Durieux ME. The goose and the gander. Anesth Analg 2016; 122: 583-5.

13. World Health Organization. Model List of Essential Medicines, $19^{\text {th }}$ Edition - April 2015. Available from URL: http://www.who. int/medicines/publications/essentialmedicines/EML_2015_FINAL_ amended_NOV2015.pdf?ua=1 (accessed December 2016). 